\title{
4G Rights and Criminality
}

\author{
Antonios Maniatis* \\ Professor of Fire Service Academy, Greece \\ *Corresponding author: Antonios Maniatis, Professor of Fire Service Academy, Greece
}

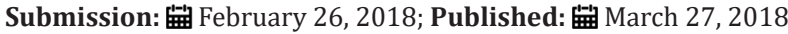

\section{Introduction}

In the current era of globalization and the advent of new technologies, the world has become more complicated. In a parallel way, criminals become more and more innovative, in order to achieve their goals. A sound example comes from cultural law, which constitutes a separate field of law with a very great impact, especially in the legal orders of "archeological countries" (Greece, Italy, Egypt). The problem of illicit archeological excavations and of antiquities smuggling constitutes a diachronic form of criminality. As thefts were increasing in museums and archeological sites in the countries of the South, humanity was led to adopt a specific normativity. To cope with the international illicit trade of cultural goods, the Convention on the Means of Prohibiting and Preventing the Illicit Import, Export and Transfer of Ownership of Cultural Property was created, in 1970.

This UNESCO convention did not block this kind of criminality, but it has made it less open. From the informal "three foot rule", Western museums, such as the Metropolitan Museum of Art of New Work, were led to turn down offers of antiquities having a suspicious origin. In this context, a new era emerged, the era of $3 \mathrm{G}$ fundamental rights in the global history of consecration of human rights. In the same decade, new rights, such as the ones to world heritage, to the environment and to water (particularly the drinking one), began to be consecrated, initially in the framework of international organizations.

From 1992 and on, humanity has proceeded to the recognition of original guarantees, like the rights that are relevant to the Information Society. The dynamic invasion of computers into society has caused problems, not only in technical and economical level but also in legal and ethical one. The world of computers and particularly of Internet does not constitute merely the field of action of cybercriminals but also the "refugium" of their acts. "Electronic criminals" leave neither traces nor fingerprints and hacking has entered its most significant period, worldwide. However, if the 4G period of guarantees has been associated almost exclusively to the rights relevant to Information Society, an alternative concept gains territory, according to which the modern generation has the CCC right as one of its emblematic rights. Anyway, the generation on the matter includes also other rights, focusing inter alia on the world of animals and on the acts of bioethical interest and particularly the protection from genetic engineering interventions. DNA has been conducive to success in many crime cases, handled by prosecution authorities; even as far as archived cases of old facts are concerned. If forensic science has emerged due to the advent of the fingerprints method in the framework of criminal law trials, its new era is related to DNA use in these trials.

The puzzle of criminality is particularly difficult to cope with, as exemplified by what has become known as "Chippindale's law" in the matter of loss of archeological data: "whenever one takes an interest in anything to do with illicit antiquities, reality is always worse that what was expected". It is also to add that archeological heritage is also exposed to the danger of arsons, exemplified by the 6th generation of arsons that hit Galicia in October 2017. It is to make a special reference to the fact that petro glyphs, aged 4,000 years old, were damaged. It is like burning the famous Spanish cave of Altamira, included in the world heritage list since 1985 and therefore having to do with the aforementioned 3G fundamental right to heritage. In the current era of $4 \mathrm{G}$ rights, comparative criminal law has been recently endowed with a new normatively, focusing on the new concept of criminal organization, exemplified by groups of antiquities looters or arsonists.

Last but not least, a "forgotten" right has recently emerged, in international scale. It is about the right to pursuit of happiness, which was consecrated as one of the unalienable human rights, along with the ones to life and freedom, in the 1776 Declaration of Independence of the USA. The Italian philosopher Gaetano Filangeri had already introduced the concept of "right to happiness" in his work "The Science of Legislation" and Benjamin Franklin, the father of the Declaration, was inspired by that concept. Furthermore, the right was incorporated as a scope in the first fundamental text of the French Revolution, in 1789, but afterwards was omitted, in the Constitutions. However, a part of the doctrine has recently highlighted its existence, although there is still a controversy on the matter. Indeed, both doctrine and jurisprudence remain reluctant to recognize it. Although it could be ranked among the classical rights, it is about essentially a new entry in the list of $4 \mathrm{G}$ rights. Not only does it exist but it is related to public policies against criminality, particularly the one committed by intent and exemplified by the undetectable, serious case of arsons in Galicia. 
Creative Commons Attribution 4.0 International License

For possible submissions Click Here

Submit Article

Forensic Science \& Addiction Research
Benefits of Publishing with us
- High-level peer review and editorial services
- Freely accessible online immediately upon publication
- Authors retain the copyright to their work
- Licensing it under a Creative Commons license
- Visibility through different online platforms

